\title{
COMPARISON SPIRAL PIPE WITH ROUND PIPE FOR HEAT TRANSFER IN BOILER GAS TURBINE
}

\author{
ISMAIL THAMRIN*, K. NOVALDO \\ Department of Mechanical Engineering, Faculty of Engineering, Universitas Sriwijaya, Palembang, \\ Indonesia
}

*Corresponding author: ismailthamrin@ft.unsri.ac.id (Received: 10 October 2020; Accepted: 15 November 2020; Published on-line: 31 November 2020)

\begin{abstract}
The increasing need for energy requires finding alternative energy. Sawdust is waste but can be utilized as alternative energy. The sawdust is used as a boiler fuel called biomass. However, the utilization of sawdust as a boiler fuel is considered less effective. Presumably heat and mass transfer of steam for boiler system using spiral pipes. Since the length of steam distribution becomes long so that the heat transfer from the boiler to pipes takes a long time. Thus, this study examines the effect of spiral pipes for the heat transfer process for boilers, where the steam is supplied to rotate the turbines (generate electricity). Based on the initial study, the boiler system performance using a spiral pipe is better than a round pipe.
\end{abstract}

KEYWORDS: Boiler, Gas turbine, Spiral pipe, Heat transfer.

\section{INTRODUCTION}

The increase in population growth has an impact on the increasing electricity demand. In 2019 , Indonesia has a power generation capacity of $64.5 \mathrm{GW}, 86 \%$ using fossil fuels [1][2]. As consequence, power generation and its fuel have increased [3].

Indonesia's supply of fossil fuels is dominated by imports [1], the demand for increased energy, the power generation based on new and renewable energy is the right alternative.

Sawdust waste is a potential raw material for biomass, where it is abundant [4][5]. Sawdust waste is alleged to be used as combustion material to heat the boiler [6][7][8]. The steam produced by the boiler is used to rotate the turbine and then it can generate electricity [9][10][11]. Increased performance of the boiler by reheating the steam [12][13][12][14].

Based on previous research, the utilization boiler as chamber sawdust can be applied [15]. However, the performance of the boiler system is low. This presumably because the heat transfer process is not yet optimal. For this reason, the spiral pipe is proposed as a steam distributor from the boiler to the turbine. Thus, this study to determine the effect of the spiral pipe as a distributor of steam from the boiler to the gas turbine.

\section{METHOD}

\subsection{Performance Analysis}

The heat needed to raise the water temperature to $100^{\circ} \mathrm{C}$ :

$$
Q_{1}=m c_{p} \Delta T
$$

Next, the heat needed to convert $100^{\circ} \mathrm{C}$ water temperature to steam: 


$$
Q_{2}=m L
$$

Then, the heat needed to raise temperature steam more than $100^{\circ} \mathrm{C}$ :

$$
Q_{3}=m c_{p} \Delta T
$$

Analysis of the conversion in the water phase from liquid to steam can be seen in Figure 1. In $\mathrm{Q}_{1}$, the water temperature is increased by $100^{\circ} \mathrm{C}$. After the water temperature $100^{\circ} \mathrm{C}$, the water phase (liquid) is converted into steam. Then, the steam is heated until the steam dries, the heat analysis using Equation 4.

$$
Q_{\text {superheater }}=\dot{m} c_{p} \Delta T
$$

Furthermore, the boiler performance boiler is calculated using Equation 5:

$$
\eta_{\text {boiler }}=\frac{Q_{\text {in }}-Q_{\text {out }}}{Q_{\text {in }}} \times 100 \%
$$

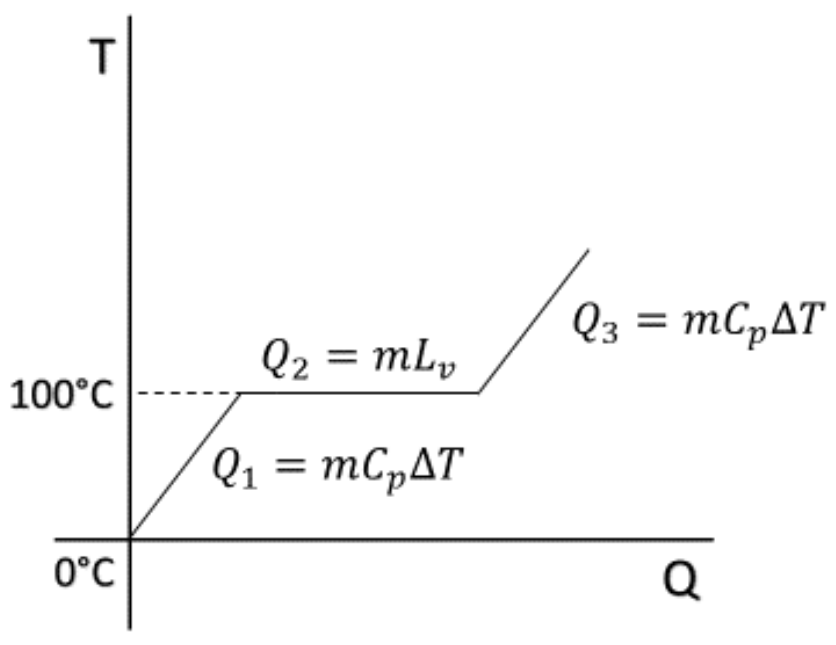

Fig. 1. Relation of heat with temperature.

\subsection{Experimental Setup}

Testing using a mini boiler. The mini boiler does not use a condenser. The schematic of the apparatus can be seen in Figure 1.

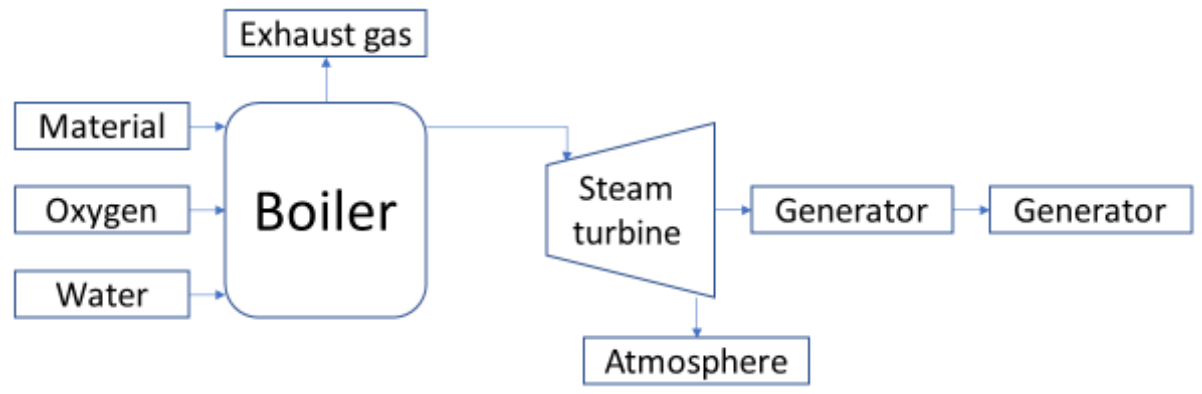

Fig. 2. Schematic of the experimental setup.

The mini boiler used has four devices: furnace, superheater, economizer, and safety valve. A furnace is a place for burning sawdust waste. Heat transfer to water is conducted through 
spiral pipes, where the spiral pipes on the furnace wall. There are three processes of heat transfer by the furnace to the spiral pipes: radiation, convection, and conduction.

A superheater is a steam drying place. The steam from the spiral pipe is still wet so it cannot be used. The steam is dried at temperatures above $100^{\circ} \mathrm{C}$. An economizer is a place to heat water and previously condensed water. The safety valve serves to remove steam when the pressure has exceeded the limit. This valve consists of two devices: a wet steam safety valve, and a dry steam safety valve. The boiler is made of $2.5 \mathrm{~mm}$ thick steel plate with a volume of $0.384 \mathrm{~m}^{3}$ ( $0.8 \mathrm{~m}$ length, 0.8 widths, and 0.6 height). In the center of the boiler is a combustion chamber and beside it is a place to contain water. The steam that has been produced is then flowed using a spiral pipe, where the spiral pipe located in the center of the chamber, to generate the steam becomes dry. The dry steam flows into the turbine. The boiler schematic can be seen in Figure 3.

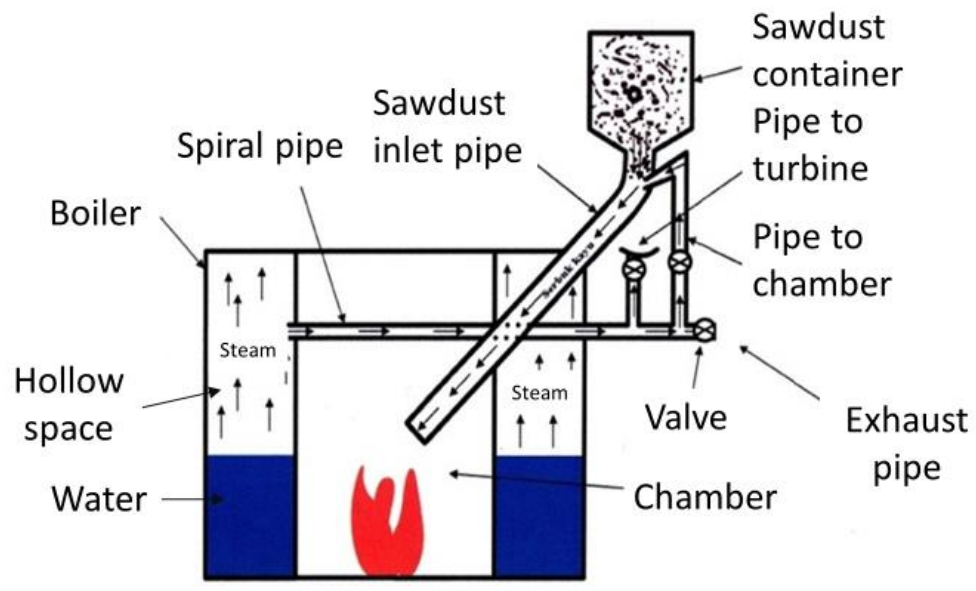

Fig. 3. Schematic of the boiler.

The spiral pipe used has a diameter inner $\left(D_{\text {in }}\right)$ of $1.58 \mathrm{~cm}$ and diameter outer $\left(D_{\text {out }}\right)$ of $2.13 \mathrm{~cm}$ with a length of $196.8 \mathrm{~cm}$. As a comparison, the round pipes with a size of 0.5 inches with a length of $182 \mathrm{~cm}$ were used. The test is carried out 5 times with a mass of water is 83.7 $\mathrm{kg}$.

\section{RESULTS}

Data on the water mass before and after testing can be seen in Table 1, whereas Table 2 is the experiment results.

Table 1. Mass water before and after testing

\begin{tabular}{lcccc}
\hline \multirow{2}{*}{ Variation } & \multicolumn{2}{c}{ Temperature } & \multicolumn{2}{c}{ Water mass } \\
\cline { 2 - 5 } & Before & After & Before & After \\
\hline Spiral pipes & $29.1^{\circ} \mathrm{C}$ & $100^{\circ} \mathrm{C}$ & $83.7 \mathrm{~kg}$ & $73.32 \mathrm{~kg}$ \\
Round pipes & $28.12^{\circ} \mathrm{C}$ & $100^{\circ} \mathrm{C}$ & $83.7 \mathrm{~kg}$ & $73.65 \mathrm{~kg}$ \\
\hline
\end{tabular}

Table 2. Experimental results

\begin{tabular}{lcc}
\hline \multirow{2}{*}{ Parameters } & \multicolumn{2}{c}{ Variation } \\
\cline { 2 - 3 } & Spiral pipes & Round pipes \\
\hline Wood mass before & $30 \mathrm{~kg}$ & $30 \mathrm{~kg}$ \\
Wood mass after & $5.68 \mathrm{~kg}$ & $5.12 \mathrm{~kg}$
\end{tabular}




\begin{tabular}{lcc} 
Sawdust mass before & $3.5 \mathrm{~kg}$ & $3.5 \mathrm{~kg}$ \\
Sawdust mass after & $2.06 \mathrm{~kg}$ & $2.2 \mathrm{~kg}$ \\
$\mathrm{~V}_{\text {air }}$ & $18.48 \mathrm{~m} / \mathrm{s}$ & $17.34 \mathrm{~m} / \mathrm{s}$ \\
$\mathrm{T}_{\text {steam }}$ in hollow space & $277.64^{\circ} \mathrm{C}$ & $267.4^{\circ} \mathrm{C}$ \\
$\mathrm{T}_{\text {steam }}$ at outlet & $288.5^{\circ} \mathrm{C}$ & $284^{\circ} \mathrm{C}$ \\
$\mathrm{n}_{\text {turbine }}$ & $508 \mathrm{rpm}$ & $486.8 \mathrm{rpm}$ \\
\hline
\end{tabular}

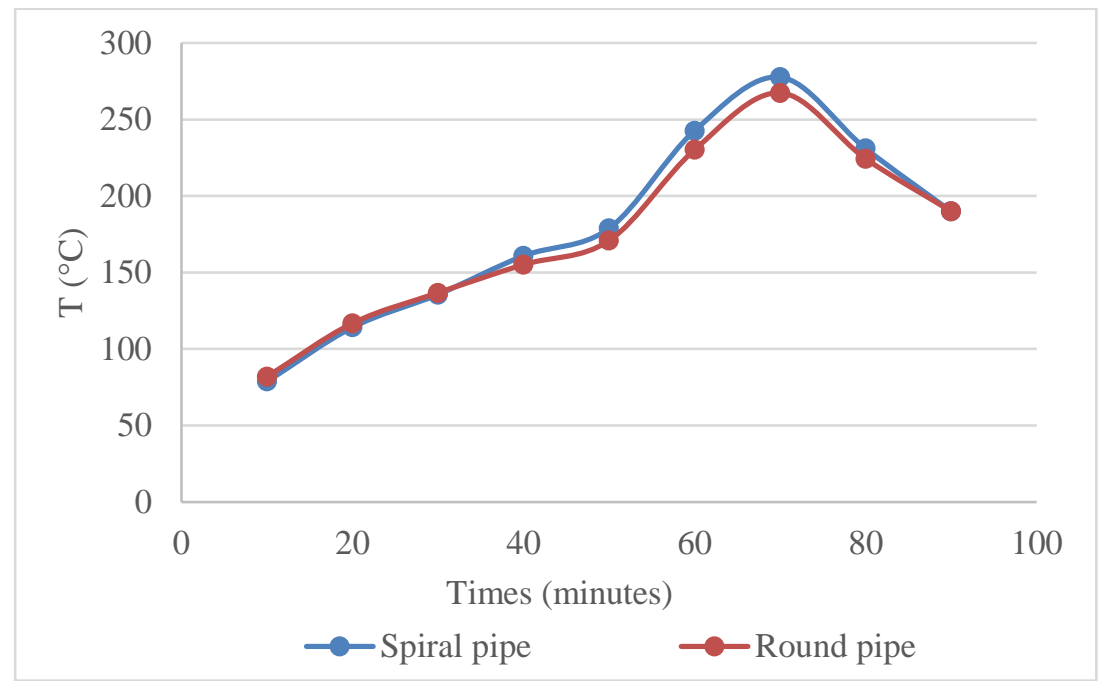

Fig. 4. The steam temperature at inlet pipe of hollow space.

In Figure 4, the maximum temperature in the inlet occurs in 70 minutes. The maximum steam temperature at the inlet for the spiral pipe is $277.62^{\circ} \mathrm{C}$ higher than the round pipe is $267.4^{\circ} \mathrm{C}$. The times from 0 to 70 minutes, the steam temperature at the inlet for the spiral pipe is higher than the round pipe (see Figure 4).

In Figure 5, an outlet of the boiler, the temperature for spiral pipe system is higher than of round pipe. From Figure 5, the maximum temperature at the outlet for the spiral pipe system is $288.54^{\circ} \mathrm{C}$ higher than the round piper of $284^{\circ} \mathrm{C}$ (times of 70 minutes). Since the track of steam for the spiral pipe is longer than the round pipe, so the heat transfer process is longer (length spiral pipe of $196.8 \mathrm{~cm}$ and round pipe of $182 \mathrm{~cm}$ ).

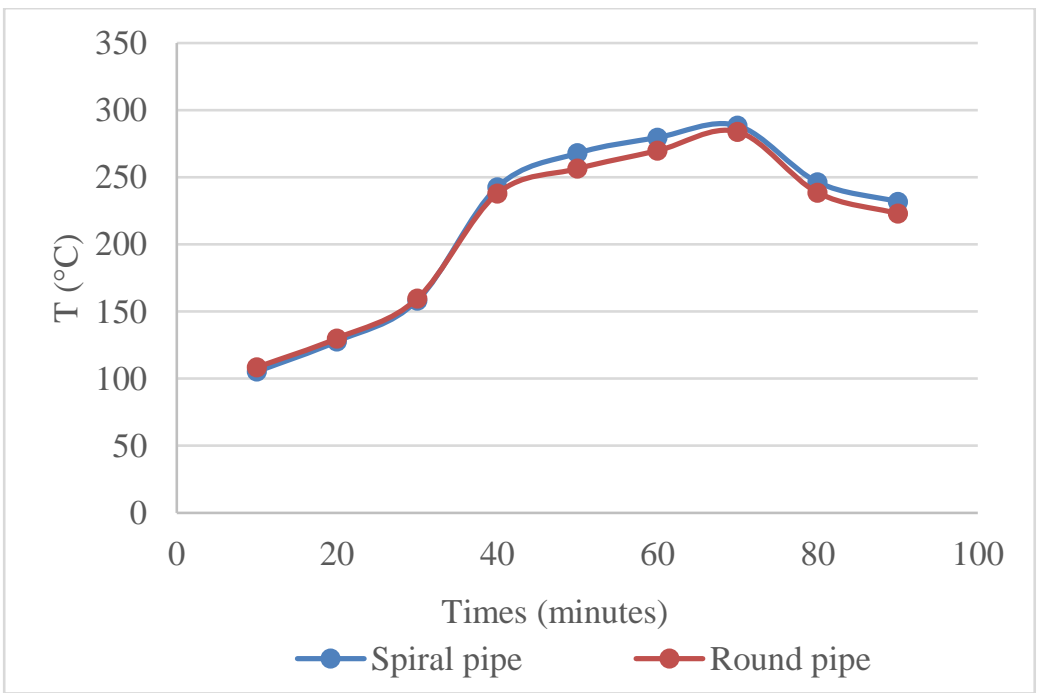

Fig. 5. The steam temperature at the outlet of the boiler. 
Comparison Figure 4 with 5 shows that there are differences in temperature change in spiral pipe systems with round pipes. The greater temperature changes occur in the spiral pipe system. This hypothesis was similar to Table 3 . Table 3 is the efficiency of the system of spiral pipe and round pipe. Analysis in Table 3 using Equation 5. Based on Table 3, the boiler performance using a spiral pipe is $14.96 \%$ higher than the round pipe is $5.63 \%$.

Table 3. Performance boiler system using spiral pipe and round pipe

\begin{tabular}{cc}
\hline System & Efficiency \\
\hline Spiral pipe & $14.96 \%$ \\
Round pipe & $5.63 \%$ \\
\hline
\end{tabular}

\section{CONCLUSION}

Initial study for utilization of spiral pipes for boiler system has been done. Spiral pipes are recommended for this boiler system. Based on the results, the boiler performance system using spiral pipes better to use the round pipe. However, it is still necessary to the characteristic of the spiral pipe shape for boiler system.

\section{ACKNOWLEDGEMENT}

The authors say thanks to Conversion Energy Laboratory-Universitas Sriwijaya, Indonesia for facilities this research.

\section{REFERENCES}

[1] Suharyati, S. H. Pambudi, J. L. Wibowo, and N. I. Pratiwi, "Outlook Energi Indonesia (OEI) 2019," Jakarta, 2019.

[2] D. Adanta and D. Febriansyah, "Feasibility Analysis of a Pico-Scale Turgo Turbine Bucket Using Coconut Shell Spoons for Electricity Generation in Remote Areas in Indonesia," Journal of Advanced Research in Fluid Mechanics and Thermal Sciences, vol. 69, no. 1, pp. 85-97, 2020, doi: https://doi.org/10.37934/arfmts.69.1.8597.

[3] D. Adanta, Budiarso, Warjito, and A. I. Siswantara, "Assessment of Turbulence Modelling for Numerical Simulations into Pico Hydro Turbine," Journal of Advanced Research in Fluid Mechanics and Thermal Sciences, vol. 46, pp. 21-31, 2018.

[4] T. R. Miles, T. R. Miles Jr, L. L. Baxter, R. W. Bryers, B. M. Jenkins, and L. L. Oden, "Boiler Deposits from Firing Biomass Fuels," Biomass and bioenergy, vol. 10, no. 2-3, pp. 125-138, 1996.

[5] G. Chen and D. Y. C. Leung, "Experimental Investigation of Biomass Waste,(Rice Straw, Cotton Stalk, and Pine Sawdust), Pyrolysis Characteristics," Energy Sources, vol. 25, no. 4, pp. 331337, 2003.

[6] T. Rajaseenivasan, V. Srinivasan, G. S. M. Qadir, and K. Srithar, "An Investigation on the Performance of Sawdust Briquette Blending with Neem Powder," Alexandria Engineering Journal, vol. 55, no. 3, pp. 2833-2838, 2016.

[7] R. K. Mishra and K. Mohanty, "Pyrolysis Kinetics and Thermal Behavior of Waste Sawdust Biomass Using Thermogravimetric Analysis," Bioresource technology, vol. 251, pp. 63-74, 2018.

[8] B. Lela, M. Barišić, and S. Nižetić, "Cardboard/Sawdust Briquettes as Biomass Fuel: PhysicalMechanical and Thermal Characteristics," Waste Management, vol. 47, pp. 236-245, 2016.

[9] M. M. Rahman, T. K. Ibrahim, and A. N. Abdalla, "Thermodynamic Performance Analysis of Gas-Turbine Power-Plant," International Journal of Physical Sciences, vol. 6, no. 14, pp. 35393550, 2011.

[10] Y. P. Olisa and K. W. Kotingo, "Utilization of Palm Empty Fruit Bunch (PEFB) as Solid Fuel for Steam Boiler," European Journal of Engineering and Technology, vol. 2, no. 2, 2014.

[11] A. Nitkiewicz and R. Sekret, "Comparison of LCA Results of Low Temperature Heat Plant Using 
Electric Heat Pump, Absorption Heat Pump and Gas-Fired Boiler," Energy Conversion and Management, vol. 87, pp. 647-652, 2014.

[12] L. Zhou, G. Xu, S. Zhao, C. Xu, and Y. Yang, "Parametric Analysis and Process Optimization of Steam Cycle in Double Reheat Ultra-Supercritical Power Plants," Applied Thermal Engineering, vol. 99, pp. 652-660, 2016.

[13] H. Barzegar Avval, P. Ahmadi, A. R. Ghaffarizadeh, and M. H. Saidi, "Thermo-economicenvironmental Multiobjective Optimization of a Gas Turbine Power Plant with Preheater Using Evolutionary Algorithm," International Journal of Energy Research, vol. 35, no. 5, pp. 389-403, 2011.

[14] G. Bonati and G. Stuckenschneider, "Apparatus and Method for Reheating Turbine Steam." Google Patents, 07-Apr-2015.

[15] Y. Fusito and I. Thamrin, "Effect of Modification of Spiral Pipes on Mini Boiler to Steam Temperature and Boiler Efficiency," in IOP Conference Series: Materials Science and Engineering, 2019, vol. 620, no. 1, p. 12118. 